\title{
DĚDICTVÍ MNICHOVSKÉ SMLOUVY A JEHO DOPADY NA AMERICKOU ZAHRANIČNÍ POLITIKU
}

\section{LEGACY OF MUNICH TREATY AND ITS IMPACT ON AMERICAN FOREIGN POLICY}

\author{
Pavel HLAVÁČEK*
}

\begin{abstract}
Abstrakt
Snažíme se dokázat, že odkaz Mnichova, potažmo politika appeasementu jako taková, byla chybně pochopena, respektive že získala negativní kontext teprve $v$ důsledku hrüz druhé světové války. Poučení z Mnichova po roce 1945 bylo interpretováno tak, že se nikdy nesmí diktátorům ustupovat. Na tuto chybnou interpretaci se odvolávali všichni američtí prezidenti, s výjimkou Jamese Cartera, aby ospravedlnili svou zahraniční politiku. Tato logika, kterou označujeme jako „mnichovské paradigma“, hrála významnou roli v rozhodování, zda Spojené státy vstoupí do války v Koreji, Vietnamu, Iráku (2krát), Kosovu aj. Domníváme se, že analogie s Mnichovem (či druhou světovou válkou) není adekvátní a je čas se zamyslet, zda by neměla zmizet ze zahraničněbezpečnostního slovníku (nejen) Spojených států.
\end{abstract}

\begin{abstract}
In the following article we argue that the Munich Agreement (1938) - or generally the policy of appeasement itself - has been misunderstood and has been given negative content only due to the horrors of the Second World War. The lesson of Munich after 1945 led to false conclusion that the only way one might face dictatorship is never to negotiate. All US presidents - with the exception of Jimmy Carter - used Munich analogy in order to legitimize their foreign policy. This logic, we might call the Munich paradigm, played an important role in decision making process before the US interventions in Korea, Vietnam, Iraq (twice) and Kosovo. We believe that any analogy to Munich (or World War Two) is not adequate. It is time to think whether such analogy should not be avoided (not only) in the American foreign and security debate.
\end{abstract}

\section{Klíčová slova}

Mnichovská smlouva, paradigma Mnichova, politika appeasementu, americká zahraniční politika po roce 1945, vietnamská válka, vietnamské paradigma.

\section{Keywords}

Munich agreement, Munich paradigm, policy of appeasement, American foreign policy since 1945, Vietnam war, Vietnam paradigm.

\section{ÚVOD}

Mnichovská smlouva a americká zahraniční politika po druhé světové válce jsou zdánlivě těžko slučitelná témata. V době, kdy se konference v Mnichově odehrála, Spojené státy stále dodržovaly politiku neutrality. Samotné důsledky smlouvy byly navíc za války anulovány a ze Spojených států se supervelmoc stává fakticky až po porážce nacistického Německa. Přesto jsou si tyto události velmi blízké, chápeme-li odkaz Mnichova především v psychologické rovině. Odkazování na „Mnichov“ či „mnichovanství“ je v tomto případě synonymem politiky

*E-mail: hlavacek@kap.zcu.cz 
appeasementu, kterou uplatňovala Velká Británie v druhé polovině 30. let minulého století. Tato politika byla po 2. světové válce spojována s celkovým selháním demokratických mocností, které svou nečinností umožnily vzestup moci Adolfa Hitlera.

V první části práce se proto snažíme poukázat na to, že jednání premiéra Chamberlaina nelze označit jako naivní a nezodpovědné, jak se často traduje. Přesněji řečeno dokazujeme, že mnichovské události a politika appeasementu začaly být negativně vnímány teprve $\mathrm{v}$ důsledku válečných hrůz. Původně appeasement označoval snahu dosáhnout kompromisu pomocí vzájemných ústupků. Šlo o neutrální výraz. Teprve po roce 1945 se appeasement stal symbolem chybné strategie, která ze své podstaty, tj. ustupování nepř́íteli, otevírá cestu dalšímu konfliktu.

V druhé části zasazujeme odkaz mnichovských událostí do kontextu zahraniční politiky USA. Spojené státy jako vedoucí velmoc Západu měly přirozený zájem, aby se podobný vývoj již neopakoval. Po válce si ve Washingtonu začali politiku appeasementu interpretovat tak, že nejlepším způsobem, jak čelit nepříteli, je nikdy neustupovat, a pokud vůbec vyjednávat, jedině z pozice síly (aby ustupoval pouze protivník). Toto uvažování silně ovlivnilo generaci politiků, která do Bílého domu nastoupila po roce 1945, a stálo za tím to, co označujeme jako mnichovské paradigma. Mnichovským paradigmatem míníme vzorec jednání, kdy je v zahraniční politice upřednostňována vojenská síla před vyjednáváním.

Tento vzorec se stal součástí širšího studenoválečnického konsenzu, který narušila teprve vietnamská válka. Jestliže v prvních dvou dekádách po skončení 2 . světové války formovalo myšlení amerických státníků a diplomatů mnichovské paradigma, pak jej přibližně od poloviny 70. let dočasně nahrazuje paradigma vietnamské. Toto paradigma chápeme jako protipól paradigmatu mnichovského (tj. jako vzorec chování, kde je diplomacie a jednání a priori upřednostňováno před silovými argumenty). Vietnamské paradigma převládlo u Jimmyho Cartera (1977-1980).

Stěžejní částí našeho textu je analýza jednotlivých administrativ a jejich využití mnichovského paradigmatu. Postupujeme chronologicky, všímáme si, jak konkrétně byla analogie na Mnichov aplikována, v jakém kontextu ospravedlňována, přibližujeme kontext rozhodovacího procesu a poukazujeme na to, v čem je analogie zavádějící. Snažíme se dokázat, že paradigma vzniklé v důsledku politiky appeasementu, v širším slova smyslu v důsledku 2. světové války, je chybné a mělo by zmizet z terminologie zahraničněbezpečnostního slovníku.

\section{INTERPRETACE MNICHOVSKÝCH UDÁLOSTÍ}

Výklady mnichovské konference a toho, co ji předcházelo, se výrazně liší podle toho, kdy a kým byly prezentovány. Zatímco pro Československo znamenal konec září 1938 začátek národního ponížení, v Evropě byl podpis smlouvy vítán veskrze pozitivně. Ihned po svém návratu z Německa byl letoun Nevilla Chamberlaina na letišti obklopen davem jeho př́znivců a stejná situace se opakovala po jeho př́ijezdu do Downing Street. Ministerský předseda dvakrát předstoupil před lid, kde mimo jiné tvrdil, že přináší „,mír se ctí“, který se stane „,mírem naší doby“. ${ }^{\text {’ }}$

V London Times se hned druhý den ráno (1. října) v úvodníku psalo: „Žádný přemožitel se nevrátil z vítězné bitvy tak obdivován vavříny vítězství, jako pan Chamberlain včera z Mnichova; král i lid prokázali svým přivítáním díky jeho dosaženým výsledkům. “² Nevile Henderson, britský ambasador v Berlíně, svému premiérovi v reakci na mnichovská jednání napsal: „Milióny matek budou dnes v noci uctívat vaše jméno za to, že jste zachránil jejich syny před hrůzami války. “33

Je důležité si uvědomit, že to, co z ,appeasementu“ učinilo symbol zrady a slabošství, byla teprve 2. světová válka a hrůzy holocaustu. V září 1938 by žádná britská vláda nebyla ochotna jít do války, aby bránila zemi, se kterou neměla uzavřenou vojenskou alianci. Opozice proti britské zahraniční politice druhé poloviny 30. let existovala, ale byla velmi roztř́štěná. Neville Chamberlain dobrovolně rezignoval a definitivně ukončil politiku appeasementu po napadení Polska. Navzdory tomu nový premiér (Winston Churchill) svého odstupujícího kolegu požádal, aby 
zůstal šéfem Konzervativní strany i členem kabinetu. Toto gentlemanské gesto napovídá, že přes odlišné názory Churchill zůstal Chamberlainovým spojencem. ${ }^{4}$

Kritikové zahraniční politiky premiéra Chamberlaina nedokázali ve své době nabídnout alternativu. Po válce pak přispěli k vytvoření několika mýtů, které přežívají dodnes. Jedním z nich je Churchillovo tvrzení, že „V historii nebylo války, které by šlo snadněji předejít časově naplánovanou akcí spíše než této [válce], která zcela zpustošila svět. Dalo se tomu zabránit, aniž by došlo k výstřelu z jediné zbraně“. 5 Winston Churchill jinými slovy obhajoval tvrzení, že Hitlera bylo možno zastavit, aniž by mu byla vyhlášena válka. Omyl tohoto argumentu vychází z předpokladu, že německý vůdce byl racionální aktér, a tudíž jej bylo možné zastavit odstrašením. Unikátnost nacistického režimu ale spočívala právě v tom, že Hitlera zastavit nešlo. Největším omylem britské vlády za takových okolností nebylo to, že se pokusila s Hitlerem vyjednávat. Chamberlain chyboval teprve ve chvíli, když Hitlerovi ustoupil prakticky ve všech bodech, protože jediným způsobem, jak jej zastavit, bylo zahájit válku. Hrozba válkou ani usmiřování nefungovalo. ${ }^{6}$

Důležité však je, že varianta preventivní války nebyla vůbec zvažována. Nikoli pouze pro nedostatek vůle, jak tvrdí kritici appeasementu, ale hlavně pro nedostatek prostředků na válku - od nepřipravenosti armády, nedostatku financí až po neexistenci válečné strategie. Podle Jeffereyho Recorda z Air War College, který se otázkou Mnichova dlouhodobě zabývá, byla pro Británii a Francii „rázná preventivní válka proti nacistickému Německu morálně nepřijatelná, politicky neprůchodná a vojensky neproveditelná“" 7 Z tohoto úhlu pohledu můžeme konstatovat, že Chamberlain neustupoval proto, že byl naivním idealistou, ale především chladným realistou. Jeho politiku appeasementu můžeme rovněž vnímat jako jednoznačnou snahu získat čas. Vyjednávání mu sloužilo jako prostředek dohnat Německo ve zbrojení, nikoli jako cíl. Norrin M. Ripsman a Jack S. Levy v podzimním čísle časopisu International Security (2008) dokazují, že britská vláda si nikdy o Hitlerových záměrech nedělala iluze. Nicméně politiku appeasementu hodlala odvolat až koncem desetiletí, kdy očekávala, že se vojenská rovnováha opět vychýlí ve prospěch Londýna. ${ }^{8}$

Tento názor vysvětluje, proč Británie odmítla bránit relativně dobře vyzbrojené Československo, aby o rok později vstoupila na obranu Polska, které vojensky nemělo proti Německu šanci. Stejně tak vypovídá o těchto motivech i jednání Winstona Churchilla. Když jej v červnu 1938 navštívil Hubert Ripka, tehdejší důvěrník prezidenta Beneše, Churchill českému diplomatovi bez vytáček potvrdil, že sice s appeasementem nesouhlasí, avšak, kdyby byl ve vládě, prováděl by stejnou politiku jako stávající premiér. ${ }^{9}$ Paradoxně to byl právě Chamberlain, který si slabosti appeasementu uvědomoval a od poloviny 30. let vyzýval k modernizaci britské armády a navýšení rozpočtu ministerstva obrany. ${ }^{10}$

\section{HARRY S. TRUMAN (1945-1953)}

První americký prezident, který využil analogie Mnichova, aby ospravedlnil vlastní politiku, byl Harry Truman, a to v souvislosti s vypuknutím korejské války (25. 6. 1950). Zpráva o komunistické invazi jej zastihla na dovolené ve městě Independence (Missouri). Jeho první reakce údajně zněla: „Proboha, tak at’ si ji nechají!“ (míněno komunisté Koreu, pozn. autora) ${ }^{11}$ Nicméně hned př́šstí den se vrátil do Washingtonu a dal za pravdu té části ministerského sboru, která se dožadovala razantní odpovědi. Truman uvěřil, že pokud by se Spojené státy komunistům v Koreji nepostavily ihned, mohlo by to zvrátit rovnováhu moci a ohrozit celý svobodný svět. Jak později prohlásil, komunistický útok u něj vyvolal vzpomínky na 30. léta. „Vzpomněl jsem si, že pokaždé když demokracie nedokázaly zakročit, povzbudilo to agresora, aby šel ještě dál. Komunismus jednal v Koreji jako Hitler, Mussolini a Japonsko před deseti, patnácti a dvaceti lety předtím... Pokud by toto zůstalo bez odezvy, vyústilo by to v třetí světovou válku, přesně tak jako před 2. světovou válkou. “12 Situace se prezidentu Trumanovi zdála tak vážná, že nechal vyslat letku 10 bombardérů B-29 strategického letectva z USA na Guam, aby zvážil jejich případné nasazení 
pro jaderné bombardování. ${ }^{13} \mathrm{~K}$ této eventualitě, jak víme, nedošlo, naopak to byl sám prezident Truman, který možnost použití jaderných bomb zcela smetl ze stolu.

Trumanova analogie mezi komunistickou invazí v Koreji (léto 1950) a vývojem v Evropě v roce 1939, resp. Japonskem v roce 1941, byla přinejmenším zavádějící. Americký prezident zapomněl vzít v úvahu, že k invazi by patrně nikdy nedošlo, pokud by se Washington sám nezřekl garance bezpečnosti korejského poloostrova. Stalin odmítal podpořit sjednocení Koreje až do poloviny ledna 1950, kdy si přečetl nedávné prohlášení ministra zahraničí USA Deana Achesona. Acheson hovořil o americkém bezpečnostním perimetru v Pacifiku, ale Jižní Koreu nezahrnul do pásma americké obranné linie. Slovy Henryho Kissingera se Acheson výslovně „,zřekl jakéhokoli úmyslu zaručit se za území ležící na asijské pevnině“. ${ }^{14}$ Sovětský vůdce si konfrontaci s USA nepřál, ale Achesonova slova si logicky interpretoval tak, že v př́ípadě války Amerika Jižní Koreu nebude bránit. Stalin severokorejskou invazi nakonec podpořil, avšak jeho souhlas nelze vykládat jako počátek globálního tažení mezinárodního komunismu. ${ }^{15}$

Analogie Mnichova evokovaná korejskou válkou hrála vedle samotného rozhodnutí bránit Soul rovněž klíčovou roli při vytváření Národní bezpečností strategie USA. Tu inicioval prezident Truman po pádu Čankajška. Vzniklá zpráva, označována jako dokument Rady národní bezpečnosti (National Security Council) číslo 68 (NSC - 68), se stala klíčovým vodítkem pro americkou zahraniční politiku v době studené války. NSC - 68 vychází ze dvou základních předpokladů: 1) Globální rovnováha moci se od 2. světové války vychýlila ve prospěch dvou center (tj. USA a SSSR).; 2) Sovětský svaz je unikátní diktatura vedená „novým fanatickým přesvědčením absolutní nadvlády nad zbytkem světa“. ${ }^{16}$ Zpráva z toho vyvozuje, že Moskva má ambice rozšiŕrit svou moc na celou Eurasii. Dokument 68 ze Sovětského svazu učinil globálního aktéra, který stojí za jakýmkoli komunistickým povstáním proti Západu; nerozlišoval mezi komunismem v Evropě a národněosvobozeneckým bojem ve třetím světě. Všechny komunisty zahrnoval do jedné kategorie. Prezident Truman nejprve NSC - 68 odmítl (duben 1950) jako neopodstatněný a přespř́liš nákladný dokument. Teprve když došlo k rozpoutání korejské války, změnil svůj názor a v září 1950 ho nechal schválit. Kdyby obsah NSC - 68 a Trumanovo přirovnání k 2. světové válce měly své opodstatnění, logicky by Spojené státy musely v Koreji usilovat o bezpodmínečné vítězství (jako proti Německu a Japonsku). Taková varianta se ale ukázala jako nereálná a představa totální porážky komunistů jenom oddalovala mírové rozhovory.

\section{DWIGHT D. EISENHOWER (1953-1961)}

Neschopnost Harryho Trumana ukončit korejskou válku přispěla k volebnímu vítězství republikána Dwighta D. Eisenhowera. Novému prezidentovi se sice podařilo prosadit mír v Koreji, avšak již v době jeho inaugurace (leden 1953) se začala prudce zhoršovat bezpečnostní situace ve Francouzské Indočíně. Konflikt v Indočíně vyvrcholil (na jaře 1954) bitvou o Dien Bien Phu. Když se ukázalo, že pozice Francouzů jsou neudržitelné, začala Paříž jednat o možné pomoci USA. Jedinou výhradou prezidenta Eisenhowera byla podmínka, že souhlas musí vyjádřit i Kongres. Američtí zákonodárci trvali na tom, aby na válce participovali také další spojenci, zejména Velká Británie, Austrálie a Nový Zéland. Vše ale záleželo především na rozhodnutí Londýna.

Americký prezident napsal (4. dubna) premiéru Churchillovi osobní dopis, v němž varoval, že pád Indočíny by měl dopad na celý region. Ve stěžejní části pak uvedl: „V mnoha ohledech tato situace připomíná tu, kterou jste tak výstižně popsal [před začátkem bitvy o Anglii v červnu 1940]... Dovolím si opět odkázat na historii: nedokázali jsme zastavit Hirohita, Mussoliniho a Hitlera díky tomu, že jsme nejednali jednotně a včas. To stálo na počátku dlouhých let hluboké tragédie a smrtelného nebezpečí. Je možné, aby se naše národy z této lekce nepoučily?“17 Eisenhower těmito slovy potvrzuje, že trpěl mnichovským komplexem stejně jako Truman. Využívá analogie mezi situací v Evropě krátce před vypuknutím letecké bitvy o Anglii, bitvy, kterou Churchill popsal jako rozhodující pro celé křest’anstvo, a situací v Indočíně roku 1954 
v př́ípadě francouzské porážky. Eisenhower se snažil svému příteli ukázat, že Ho Či Min pro budoucnost svobodného světa znamená stejnou hrozbu jako vítězství Adolfa Hitlera za druhé světové války.

Churchilla tyto argumenty zjevně neoslovily, už jen proto, že Británii svazovala partyzánská válka v Malajsii. Stárnoucí velikán britské politiky potvrdil své skeptické výhrady. Vojenská akce v Indočíně by mohla ohrozit postavení Západu na připravované konferenci v Ženevě (1954). Churchill nabídku Američanů odmítl, čímž ukončil veškeré spekulace o možné intervenci.

Než Bílý dům obdržel oficiální odpověd', byl prezident Eisenhower na tiskové konferenci ze dne 7. dubna dotázán na význam Indočíny pro svobodný svět. Ačkoli americká hlava státu zopakovala již známé argumenty, vůbec poprvé novinářům popsala „dominový efekt“, který by v př́ípadě komunistického vítězství zasáhl celý region: „Máte před sebou rozestavěnou řadu kostek domina, převrhnete první, a je jasné, že poslední padne velmi rychle. A takto může přijít začátek rozpadu s těmi nejvážnějšími následky. “18 Indočína podle amerického prezidenta tvořila „základní kámen svobodného světa v jihovýchodní Asii“, a pokud by připadla komunistům, pak i „Barma, Thajsko, Indie, Japonsko, Filipíny a přirozeně Laos s Kambodžou jsou mezi těmi, jejichž bezpečnost by byla ohrožena“. ${ }^{19}$ Nikdy nebylo vysvětleno, jak by porážka francouzských kolonií v Indočíně mohla zvrátit světovou rovnováhu. Podobně nebyl nalezen žádný důkaz, že by Vietminh ovládala Moskva či Peking. Přesto měla teorie domina elektrizující účinek $\mathrm{s}$ takřka nezpochybnitelným postavením. I když se jí dovolával až prezident Eisenhower, aplikována byla de facto již administrativou prezidenta Trumana (byt' tak ještě nebyla označována). Když Dean Acheson obhajoval pomoc Řecku a Turecku (1947), argumentoval přesně v intencích dominového efektu: „Sovětský tlak na úžiny, na Írán a na severní Řecko přivedl Balkán do bodu, kde by vysoce pravděpodobný sovětský průlom otevřel Sovětům cestu na tři kontinenty... Tato infekce by se rozšíriila dál do Afriky přes Malou Asii a Egypt a do Evropy přes Itálii a Francii, které jsou již nyní ohroženy nejsilnějšími komunistickými stranami v západní Evropě.“20 Teorii domina využije i prezident Kennedy v souvislosti s nutností ubránit nekomunistický Laos a po něm prezident Johnson a Nixon v souvislosti s Jižním Vietnamem. Proč se žádný z představitelů obou politických stran nepokusil o kritické zhodnocení teorie domina, zůstává předmětem diskuse. Možné vysvětlení předložil profesor Paul Conway, když tvrdil, že její logiku je třeba hledat ve 2. světové válce a „lekci z Mnichova“, tj. snaze „nikdy se nepodvolit teritoriálním požadavkům agresivního, vojenského diktátora“. ${ }^{21}$

Zpochybnění teorie domina by vedlo k celkovému podkopání studenoválečnického konsenzu. Dokud bylo národněosvobozenecké hnutí chápáno jako snaha Moskvy nebo Pekingu o ovládnutí světa, pak žádný americký prezident nemohl zůstat nečinný. Neochota postavit se (komunistickému) zlu či snaha o vyjednávání by byla interpretována jako slabost, též mnichovanství nebo appeasement. Prezident USA, který si nárokoval titul ,vůdce svobodného světa“, nesměl za žádných okolností vypadat jako Chamberlain.

Když skončila bitva o Dien Bien Phu (květen 1954), byla v Ženevě zahájena jednání o budoucnosti Indočíny. Prezident Eisenhower i ministr zahraničí John F. Dulles se konference zúčastnili, nicméně v obavě, aby nebyli nařčeni z „mnichovanství“, se odmítli k závěrečné smlouvě připojit. S čínskou delegací si američtí představitelé odmítli podat ruce a omezili se na prohlášení, že obsah ženevské smlouvy budou USA respektovat i bez jejich podpisu. ${ }^{22}$

\section{JOHN F. KENNEDY (1961-1963)}

V průběhu tisíce dní, které John F. Kennedy strávil v Bílém domě, se objevily tři bezpečnostní výzvy, na nichž lze ilustrovat Kennedyho selektivní přístup k mnichovskému paradigmatu. V zásadě sice platí, že se Kennedy dovolával poučení se z chyb politiky appeasementu, jeho konkrétní jednání však tomu odpovídalo jen zčásti. 
První výzva, která otestovala vůdcovské schopnosti nového prezidenta, se odehrála na Kubě, kde se krátce předtím dostal k moci Fidel Castro. Kennedy odsouhlasil plán na jeho svržení prostřednictvím antikomunistických Kubánců. Svou podporu ale podmínil tím, že účast amerických ozbrojených sil bude omezena na minimum. At’ již tento postup ku prospěchu celé operace přispěl, nebo ne, vylodění v Zátoce sviní žalostně selhalo. Kennedy sice vzal veškerou zodpovědnost za neúspěch na sebe, avšak v soukromí si stěžoval na špatnou práci tajných služeb. „Jak jsem jen mohl zajít tak daleko? Celý život se řídím něčím jiným, abych tady poslechl tyhle experty. Jak jsem jenom mohl být takový hlupák a nechal jim to projít?,“23 řekl v narážce na plán vylodění, který mu předložila CIA.

Prakticky současně s vyloděním na Kubě se zhoršila i bezpečnostní situace v Laosu. Exprezident Eisenhower svému nástupci doporučil, aby do Laosu vyslal armádu, i kdyby se tak mělo stát bez pomoci spojenců. ${ }^{24}$ Zprvu se zdálo, že J. F. Kennedy dá Eisenhowerovi za pravdu, protože $\mathrm{v}$ intencích teorie domina se shodovali na tom, že Laos je klíčovou zemí pro přežití nekomunistické jihovýchodní Asie. Sbor náčelníků štábu se ale proti takovému řešení postavil. Předpokládal, že v př́ipadě americké intervence by se do konfliktu zapojila i Čína. Pokud by se prezident rozhodl řešit situaci vojensky, armáda doporučovala vyslat alespoň 60000 vojáků plus adekvátní letecké síly, včetně bombardérů s jadernými pumami. ${ }^{25}$

Po fiasku v Zátoce sviní Kennedy přestal věřit, že by Amerika dokázala vyhrát válku 9000 mil od svého pobřeží, když se předtím nedokázala zbavit kubánských komunistů vzdálených pouhých 90 mil. Na tiskové konferenci (23. března 1961) poněkud nečekaně ohlásil, že bude usilovat o „konstruktivní jednání mezi zainteresovanými národy a vůdci Laosu...[nebot'] k mírovému řešení problémů tohoto druhu musí všichni členové OSN přispět svým dílem““. ${ }^{26}$ Snahu o politické urovnání laoského konfliktu vyslyšel i Sovětský svaz, Severní Vietnam a Velká Británie, kteří souhlasili se zahájením hovorů. Výsledky ženevských jednání (květen 1961-červen 1962) občanskou válku v Laosu pouze zmírnily. Příznačné ale je, že se Kennedymu podruhé podařilo zabránit tomu, aby lokální konflikt přerostl v něco mnohem většího. ${ }^{27}$

V druhé polovině roku 1962 se pozornost Spojených států přsesunula zpět do Karibiku. V říjnu americké výzvědné letouny nad Kubou zaznamenaly budování sovětské raketové základny. Vzhledem k celkovému poměru strategických zbraní mezi SSSR a USA byl význam jaderných raket na Kubě zcela zanedbatelný. Přesto většina ministrů doporučila problém sovětských raket řešit vojensky (at' už formou invaze, nebo pouze konvenčním bombardováním). Místo toho Kennedy zvolil cestu námořní blokády (,karantény“) a ponechal si prostor pro možné vyjednávání s Moskvou. Když svůj postup zdůvodňoval v televizním vystoupení (22. října), neobešel se bez nepřímého odkazu na Mnichov, resp. appeasement: „Třicátá léta nás naučila, že agresivní jednání, kterému je dán volný průběh, nakonec povede k válce. Tato země [USA] je proti válce. My své slovo držíme. Naším nezpochybnitelným cílem musí být zastavení využití těchto raket proti naší a jakékoli jiné zemi a zajištění, aby byly staženy a odstraněny ze západní hemisféry.“28

Čteme-li tato slova pozorně, nacházíme zřejmý protimluv. Kennedy se na jedné straně dovolává poučení z 30. let, ale na druhé straně odmítá použít vojenskou sílu. Vůči Kubě nepoužil silnějších nátlakových prostř̌edků, než jaké užila Společnost národů vůči Itálii po napadení Habeše. Pokud se Kennedy „poučil“ z appeasementu, dalo by se očekávat, že bude jednat agresivněji. Potřetí během necelých dvou let v úřadu americký prezident nejednal tak, aby umožnil vojenské řešení. Jeho zdánlivě opatrné jednání budilo rozpaky uvnitř samotného týmu, který narychlo sestavil, aby se kubánskou krizí zabýval. Generál letectva Curtis LeMay např́íklad tvrdil, že neexistuje žádné politické řešení a že konflikt na Kubě nutně směřje k vojenské konfrontaci. Kennedyho postup označil za „tak špatný jako mnichovský appeasement““. ${ }^{29}$

Na otázku, proč se Kennedy v kritických momentech laoské i kubánské krize nesnažil svého protivníka zlikvidovat a naopak mu ponechal prostor k ústupkům, jednoduchá odpověd' neexistuje. Svou roli sehrálo mnoho faktorů, jejichž analýza by vyžadovala více prostoru. Za velmi důležitou však lze označit skutečnost, že Kennedy mnichovské události dobře znal. Svá studia na Harvardu zakončil disertační prací o politice appeasementu, kterou později vydal pod názvem „Proč Anglie 
spala“. Z toho vyvozujeme, že odkazování se na Mnichov pro Kennedyho znamenalo více než prázdné fráze o neochotě jednat s diktátory. Stručně řečeno, Kennedyho rozhodování nevycházelo ze znalosti pouhé analogie, ale především z celkového kontextu evropských událostí druhé poloviny 30 . let.

Nevyřešenou otázkou mezi odborníky zůstává, zda by Kennedy svým přístupem a svými znalostmi dovolil, aby Američané zabředli do vietnamské války. Na jedné straně stojí ta skupina, která správně poukazuje na jeho veřejná vystoupení. Kennedy obhajoval teorii domina, vždy vyjadřoval podporu saigonské vládě a během let strávených v Bílém domě navýšil počet amerických poradců ve Vietnamu z přibližně 800 na 16 000. Zdánlivě tedy není co zpochybňovat.

S odstupem několika let po jeho smrti se ale začaly objevovat informace o údajných plánech na postupné stažení americké posádky z Vietnamu. ${ }^{30}$ Tyto zprvu domněnky byly později doloženy odtajněným dokumentem NSAM-263 ${ }^{31}$, přijatým přibližně 6 týdnů před smrtí hlavy státu. V něm se uvádí, že prezident schválil plán postupného stahování amerických poradců do konce roku 1965. Prvních 1000 mužů se mělo vrátit domů již do konce roku 1963.

Pokud by k tomu skutečně došlo, stal by se Kennedy prvním americkým prezidentem, který prolomil mnichovské paradigma. Tyto otázky přesto zůstanou pouze předmětem debaty. Pro úplnost je třeba dodat, že v otázce stahování poradců z Vietnamu neexistuje konsenzus. At' už má pravdu jedna, či druhá strana, je zřejmé, že stažení by v Saigonu urychlilo pád proamerického režimu. To si Kennedy nemohl dovolit, obzvláště ne krátce před začátkem předvolební kampaně. Slaboch a usmiřovač komunistů by stěží mohl uspět v boji o prezidenta USA.

Takové projevy byly pochopitelné. „Nejvíce se Kennedy obával, aby nevypadal před ostatními jako slaboch. A jako většina válečníků studené války věřil tomu, že jediným způsobem, jak čelit Rusům a jejich společníkům, bylo vystupovat z pozice síly. “32

\section{LYNDON B. JOHNSON (1964-1969)}

V době, kdy se vlády v Bílém domě ujal Lyndon B. Johnson, se prudce zhoršovala situace v Jižním Vietnamu. Výzvědné služby prezidenta varovaly, že pokud Spojené státy nic neučiní, dojde ke zhroucení saigonské vlády již koncem roku 1964. Prezident Johnson se musel rozhodnout mezi dvěma možnostmi - bud' celý region opustí, nebo jej bude bránit. Po jistém váhání zvolil druhou variantu.

Prioritním úkolem Lyndona Johnsona nebylo řešení situace v jihovýchodní Asii, nýbrž otázka rasové segregace a budování „Velké společnosti“ (Great Society) ve Spojených státech. Protože se v zahraniční politice tolik neorientoval, často pasivně přijímal názory svých ministrů. Značný vliv na jeho rozhodování měl ministr zahraničí Dean Rusk. Podle historika Spensera C. Tuckera byl „,oslova posedlý mnichovskou konferencí “33 a válku ve Vietnamu interpretoval jako ústupek dalšímu Hitlerovi. „Základní lekcí, kterou jsem dostal za 2. světové války, bylo,“ tvrdil Rusk, „že pokud je agresorovi ponechána iniciativa, pouze to uspíśí vypuknutí války.“34

Prezident Johnson týtéž argumenty zopakoval v rozhovoru se spisovatelkou a historičkou Doris Kearns Goodwinovou: „Vše, co jsem věděl o historii, mi ř́kalo, že kdybych vypadl z Vietnamu a nechal Ho Či Mina, aby se proháněl ulicemi Saigonu, učinil bych přesně to, co Chamberlain dělal před 2. světovou válkou. “35 I když měl pochybnosti, zda je Vietnam tím správným místem pro obranu „,svobodného světa“, o stažení nikdy neuvažoval. „Kdybych umožnil komunistický převrat v Jižním Vietnamu,“ tvrdil, „dívali by se na mne jako na zbabělce a mou zemi by označili za usmiřovače (appeaser)..."36 Prezident věřil v teorii domina a fakt, že svým rozhodnutím pouze následuje konsenzuální politiku svých předchůdců. Přesto ještě během kampaně před prezidentskými volbami v říjnu 1964 váhal a prohlašoval, že nebude ,posílat americké chlapce devět či deset tisíc mil daleko, aby dělali to, co vietnamští chlapci dokážou zvládnout sami““. ${ }^{37} \mathrm{Ve}$ skutečnosti $\mathrm{v}$ té době Bílý dům již zpracovával plány na eskalaci války za účasti pravidelných amerických jednotek. 
Samotnou intervenci do Vietnamu (březen 1965) Johnsonova administrativa veřejnosti ospravedlňovala ve snímku Why Vietnam? (1965). ${ }^{38}$ Tento film účelově pracoval s černobílými záběry japonské agrese v Mandžusku, italského záboru Habeše, německého obsazení Rakouska a také mnichovské konference. Divákům byl velmi sugestivně předkládán argument, že obrana Jižního Vietnamu byla ve skutečnosti snahou vyhnout se stejným chybám, jakých se Západ dopustil během 30. let. Implicitně bylo naznačováno, že americké jednotky v Indočíně brání svobodný svět před vypuknutím třetí světové války.

Na obranu prezidenta Johnsona je nutno dodat, že kritických postojů proti prohlubování amerického zapojení v jihovýchodní Asii nebylo mnoho. Když v létě 1964 Bílý dům předkládal tzv. Tonkinskou rezoluci umožňující prezidentovi provést veškerá potřebná opatření k zastavení komunistické agrese ve Vietnamu, proti hlasovali pouze dva senátoři (Wayne Morse a Ernest Gruening). Také veřejnost podpořila schválení rezoluce z $85 \%$ a obliba prezidenta po hlasování vzrostla ze 42 na $72 \%{ }^{39}$

\section{RICHARD M. NIXON (1969-1974)}

Richard Nixon vstoupil do Bílého domu v lednu 1969. Při inauguraci 37. prezidenta USA (leden 1969) by jen málokdo očekával, že právě tento muž bude schopen dohody se SSSR ohledně omezení zbrojení, umožní přijetí ČLR do OSN (1972), uzavře dohodu o statutu Berlína (1972). Skutečnost, že tak učinil právě on, je docela paradoxní, nebot' patřil mezi nejofenzivnější antikomunisty, kteří v době studené války Bílý dům obývali. Kdyby nebylo vietnamské války, mohli bychom tvrdit, že se stal prvním prezidentem, který dokázal prolomit tabu mnichovského paradigmatu. Avšak právě jeho názory na řešení konfliktu v Indočíně dokazují, že zůstal v ,zajetí Mnichova“" přinejmenším stejně jako jeho předchůdci.

K pochopení Nixonova „mnichovského zajetí““ je třeba zdokumentovat nejen jeho léta strávená v Bílém domě. Richard Nixon vždy a usilovně vystupoval tak, aby nemohl být obviňován ze slabosti vůči komunistům. Neuznával ústupky a od začátku studené války byl znám jako jeden z nejzatvrzelejších kritiků politiky zadržování. Prezidenta Trumana obviňoval z pasivity a dával mu za vinu vítězství Mao Ce-tunga v Číně. V průběhu bitvy o Dien Bien Phu prosazoval razantní americkou pomoc obleženým Francouzům včetně možnosti použít jaderné bomby. ${ }^{40} \mathrm{O}$ jaderném řešení vietnamské války se opakovaně zmiňoval i po svém nástupu do Bílého domu. ${ }^{41} \mathrm{Když} \mathrm{se}$ americká delegace vrátila z ženevských jednání (1954), Richard Nixon doporučil prezidentu Eisenhowerovi, aby si na letišti nebral deštník, ačkoli hustě pršelo. Měl obavu, že by si novináři mohli vybavit návrat Nevilla Chamberlaina z Mnichova, který po přistání pronesl svá první slova s deštníkem nad hlavou (od té doby byl znám jako muž s deštníkem). ${ }^{42}$

Radikální názory Richard Nixon zastával v šedesátých letech. Kennedyho masivní navýšení počtu amerických poradců ve Vietnamu sice schvaloval, současně je ale považoval za nedostatečné. Odmítal výsledky ženevských dohod (1962) a prohlašoval, že je komunisty třeba z Laosu vytlačit silou. Stejně kriticky se vyjadřoval vůči Johnsonově mírovému návrhu z roku 1965. Tvrdil, že zahájit rozhovory s Vietkongem nebo Severovietnamci před jejich odchodem z Jižního Vietnamu „by bylo jako jednat s Hitlerem ještě před tím, než byl vytlačen z Francie““. 43

Na osobnosti Richarda Nixona je zarážející frekvence užití mnichovské analogie a současně to, že jeho znalosti politiky appeasementu byly jen velmi povrchní. Domníváme se tak na základě skutečnosti, že již od jara 1968 si za své volební heslo vybral termín „mír se ctí“. Pod tímto heslem se skrýval slib úplného stažení amerických vojáků z Vietnamu a ukončení války ve Vietnamu, aniž by padl proamerický režim v Saigonu. ${ }^{44}$ Nixon zjevně neměl ponětí o tom, že „,mír se ctí“ bylo heslo, které užil britský premiér po návratu z mnichovské konference. Za „mír se ctí“ Nixon označil dokonce i pařížskou mírovou dohodu (1973), která ukončovala americkou angažovanost ve vietnamské válce. ${ }^{45}$ Doposud se nikdo nepokusil vysvětlit, odkud Nixon tuto frázi převzal, případně kdo mu ji poradil. I když přijmeme to, že jeho znalosti meziválečného období byly slabé, 
je zarážející, že jej nikdo na podobnost s Chamberlainovými slovy neupozornil. Nejpravděpodobnější je, že si frázi vybavil na základě vlastních zkušeností, když nastoupil jako viceprezident do administrativy Dwighta Eisenhowera (1953-1961). Tehdy prezident Eisenhower v průběhu prezidentských voleb (1952) sliboval, že zajistí čestný konec války, resp. čestné příměří v korejské válce. ${ }^{46}$ Po svém zvolení vzkázal všem zúčastněným stranám konfliktu, že k realizaci svých slibů bude ochoten použít veškerých prostředků včetně jaderných zbraní. ${ }^{47} \mathrm{~V}$ Koreji tento odvážný kalkul vyšel a Nixonovi se mohlo zdát, že stejný „recept“ bude fungovat i ve Vietnamu.

Na rozdíl od Jižní Koreje jihovietnamský režim kapituloval již rok a půl po odchodu posledního Američana. Samotný pád saigonské vlády v Bílém domě sledoval Gerald Ford (1974-1977), nebot' Richard Nixon rezignoval v důsledku aféry Watergate. Ford se v rámci svých možností snažil obhajovat politiku svého předchůdce, celkový rozpad zahraničněpolitického konsenzu mu však bránil v jakékoli výraznější akci.

\section{INTERREGNUM JIMMYHO E. CARTERA}

Jimmy Carter se do Bílého domu dostal (1977) až po skončení vietnamské války (1964-1975). Nepatřil sice mezi odborníky na zahraniční politiku, ale dokázal reflektovat traumata, která válka v jihovýchodní Asii (1964-1975) na společnosti zanechala. Ihned po svém nástupu (1977) udělil milost všem Američanům, kteří odmítli uposlechnout povolávací rozkaz a raději se skrývali nebo utekli do zahraničí. Carter nabízel alternativu: kde dříve představitelé americké exekutivy hledali paralely s Hitlerem a 2. světovou válkou, hovořil o prohloubení spolupráce s komunistickým blokem, rozšîrení politiky détente, kontrole zbrojení, větším důrazu na lidská práva, morálku a rozvojové pomoci zemím třetího světa.

Podle některých amerických politologů by se tento přístup mohl stát základem nového konsenzu v zahraniční politice, ${ }^{48}$ ale už po nástupu Ronalda Reagana se ukázalo, že Carterova vláda je pouze přechodným obdobím. Osm let Reaganovy vlády (1980-1988) znamenalo (nejen) pro zahraniční politiku USA popření všeho, na čem prezident Carter stavěl.

\section{RONALD REAGAN (1980-1988): NÁVRAT MNICHOVSKÉHO PARADIGMATU}

Ronald Reagan považoval americké angažmá ve Vietnamu za „čestné poslání“, období détenté (1969-1979) označil za chybu a dával najevo, že se hodlá vrátit ke konfrontační politice a politice zbrojení. ${ }^{49}$ Ve svých projevech citoval Winstona Churchilla častěji než všichni američtí prezidenti dohromady. ${ }^{50}$ Steven Hayward, autor knihy „Greatness: Reagan, Churchill and the Making of Extraordinary Leaders“, to vysvětluje tím, že „,vedle záliby citovat známé výroky či moudra... Reagan zcela pronikl do churchillovského chápání politiky a to se promítlo v Reaganově př́stupu ke studené válce“. ${ }^{51}$ Připustíme-li pravdivost tohoto tvrzení, je třeba připomenout, že Reagan čerpal z pamětí, které Churchill sepsal až po 2. světové válce. V tomto duchu také Reagan pochopil význam appeasementu: jako něčeho špatného, čemu se dalo zabránit, jako souboje mezi nepochopeným Churchillem a naivním Chamberlainem. Takováto interpretace je zavádějící, i když, a v tom má Hayward pravdu, reflektuje Churchillovo (poválečné) vidění světa.

Reagan byl hluboce přesvědčen o zločinnosti sovětského režimu a jako první politik Západu deklaroval brzký pád komunismu. V jednom ze svých nejznámějších projevů z března 1983 ho označil za „,další smutnou a bizardní kapitolu v dějinách lidstva, jejíž poslední stránky jsou právě psány“. ${ }^{52}$ V témže projevu také využil analogie Mnichova, když prohlásil: „Pokud nás historie něčemu naučila, pak tomu, že krátkozraký appeasement či naivní úvahy o našich nepřátelích jsou pošetilé. Značí zradu naší minulosti a pošlapání naší svobody “" ${ }^{63}$ Při jiné příležitosti zopakoval, že „historie nás učí, že, jen když jsme silní a rozhodní, můžeme udržet mír, a dokonce i omezit nástrahy míru... „Mír“ je krásné slovo, jenže také snadno a často zneužitelné... mír je náš cíl, nikoli 
politika... Neville Chamberlain hovořil o míru jako vágní politice třicátých let a výsledek nás posunul blíže 2 . světové válce“. 54

$\mathrm{Na}$ těchto výrocích není zdánlivě nic závadného. Reagan pouze zopakoval, že politika appeasementu byla chybná. Necitoval však Churchilla jen proto, aby občanům připomněl tragédii 2. světové války. Jeho cílem bylo ospravedlnit vlastní politiku (např. intervence v Grenadě, možné zapojení americké armády v Nikaragui, výdaje na zbrojení) vůči té, kterou uplatňoval Jimmy Carter. Z reaganovského úhlu pohledu se Carter dopouštěl appeasementu, protože věřil, že se Sovětským svazem je možné vycházet po dobrém. Pro Reagana byla spolupráce dobrá, jen když SSSR ustupoval.

Namísto spolupráce hodlal Reagan využít masivních investic do zbrojení tak, aby Moskva byla nucena následovat stejný kurz. Nikoli pro zbrojení samotné, ale protože (správně) očekával, že protivník čelí hospodářským problémům a nastavené tempo nemůže vydržet. Když před Američany Reagan obhajoval nárůst armádního rozpočtu navzdory prohlubujícímu se rozpočtovému deficitu, dovolával se analogie 2. světové války: „Jedna z největších tragedií tohoto století se odehrála jen proto, že jsme umožnili rozpad systému rovnováhy moci a že jsme bezcitnému diktátorovi, Adolfu Hitlerovi, umožnili, aby zvážil všechna rizika a rozhodl se pro válku a my jsme př́liš pozdě pochopili, jak moc jsme podcenili význam silné obrany... je hloupé se domnívat, že Amerika a svobodný svět tohle nikdy nedopustí." ${ }^{65}$ Chtěl těmito slovy prezident Reagan naznačit, že bez zbrojení může Západ skončit stejně jako za 2. světové války? Logickým důsledkem takového srovnání je, že představitele SSSR je možné považovat za nacisty své doby a vyhlásit jim válku.

Přes tuto ostrou rétoriku si Reagan nikdy neuzavíral cestu $\mathrm{k}$ jednacímu stolu. A v tomto se podobal prezidentu Kennedymu. Reagan sice označoval Sovětský svaz za „ř́iši zla“, ale to mu nijak nebránilo, aby se svým sokem uzavřel smlouvu o strategických zbraních hromadného ničení.

Jednání na nejvyšší úrovni o tak citlivých otázkách vyvolávalo smíšené dojmy. Například Newt Gingrich, čelní představitel Republikánské strany, už v roce 1985 odmítal, aby americká strana o takových otázkách jednala. Plánované setkání v Ženevě označil za „nejnebezpečnější summit pro Západ od té doby, co se Hitler setkal s Chamberlainem“. ${ }^{56}$ Když měla být ve Washingtonu podepsána Smlouva o odstranění raket středního doletu, začala vlivná skupina z „Konzervativního výboru“ (Conservative Caucus) tisknout a distribuovat letáky pokreslené velkým deštníkem a pod ním portréty Hitlera, Chamberlaina, Reagana, Gorbačova a nápisem „appeasement v roce 1938 je stejně nerozumný jako v roce $1988^{\prime \prime .57}$

Dva roky od chvíle, kdy smlouva o raketách středního doletu vstoupila v platnost (1988), historie Reagana od nelichotivých obvinění plně očistila. Východní blok přestal existovat a Sovětský svaz stál na pokraji zhroucení. Navzdory „happy endu“ mnichovské paradigma $\mathrm{z}$ amerického diskurzu nezmizelo.

\section{GEORGE H. W. BUSH (1988-1993): PRVNÍ VÁLKA V ZÁLIVU}

Největší vojenskou operací pro Spojené státy se v postvietnamské éře stal zásah jednotek OSN v Perském zálivu. Už čtvrtý den po začátku irácké agrese (2. srpna 1990) se prezident Bush na setkání s britskou premiérkou Thatcherovou dohodl, že nastalou krizi bude řešit vojenskými prostředky, pokud se irácký diktátor zcela nepodvolí mezinárodnímu tlaku. ${ }^{58}$ „Uspěli jsme v boji za svobodu v Evropě,“ prohlásil o několik dní později při př́iležitosti rozmístění amerických jednotek v Saudské Arábii, ,„protože jsme my a naši spojenci zůstali pevní... Jestliže nás historie něčemu naučila, pak tomu, že se musíme bránit agresi, jinak zničíme vlastní svobodu. Appeasement nefunguje. Tak, jako jsme toho byli svědky v třicátých letech, vidíme i dnes v Saddámovi Husajnovi agresivního diktátora, který ohrožuje své sousedy. “59

První válka v Zálivu je unikátní tím, že se americký prezident musel vypořádat s odkazem Mnichova i Vietnamu. ${ }^{60}$ George W. Bush si byl tohoto dilematu dobře vědom. V mnoha projevech, které předcházely osvobození Kuvajtu, kritizoval politiku appeasementu, navozoval srovnání 
Saddáma Husajna a Adolfa Hitlera, ale vietnamské analogii se snažil vyhnout. A pokud mu byla předložena, razantně ji odmítl. Například při jednání s kongresmany (30. listopadu 1990) prohlásil: „Nepotřebujeme další Vietnam... Toto není Vietnam... Tady nepůjde o dlouhou a nerozhodnou bitvu ${ }^{61 ، ; ~ n a ~ s e t k a ́ n i ́ ~ v ~ B i ́ l e ́ m ~ d o m e ̌ ~(3 . ~ l e d n a ~ 1991) ~ z o p a k o v a l: ~ „ Z ̌ a ́ d n a ́ ~ p a r a l e l a ~ s ~ V i e t n a m e m ~}$ neexistuje.“62 Prezident Bush se ze zřejmých důvodů snažil zastavit srovnávání konfliktu v Perském zálivu s Vietnamem a debatu o válce vracel k poučení z chyb appeasementu. Varoval před opakováním Mnichova, ale neuvědomoval si, že stejné ospravedlňování používali všichni jeho předchůdci, kteří přivedli Spojené státy do Vietnamu.

Přesto Bushova diplomacie slavila úspěch doma i ve světě. V relativně krátkém čase získal Bílý dům podporu od Kongresu. Stejně rychle se mu podařilo prosadit rezoluci OSN, která umožňovala vojenské řešení nastalé situace. Prezident Bush věřil, že tento potenciál je třeba využít co nejrychleji. Snaha hledat kompromis dle jeho slov umožňovala iráckému diktátorovi získat více času pro př́ípad války a také zvyšovala pravděpodobnost, že protisaddámovská koalice nevydrží. Vzpomínky na vietnamskou válku jej navíc poučily, že bude třeba dosáhnout rychlého vítězství, dokud má válka ještě značnou podporu mezi voliči. ${ }^{63}$

Tato představa narazila na odpor zejména v řadách armádních představitelů. Ti tvrdili, že vojenskou intervenci nelze uspěchat. Pokud by měl být dán souhlas se zásahem, armádní špičky požadovaly posunout útok o několik měsíců. Zástupci armády válku chápali jako nejzazší možné řešení, přijatelné pouze tehdy, když už žádné jiné řešení neexistuje. „Zatímco armáda vyvodila z analogie války ve Vietnamu závěr, že je potřeba získat čas, aby byly vyzkoušeny i jiné možnosti předtím, než do třetího světa vyšleme naše vojáky, Bush namísto toho vyvodil závěr, že síla, pokud má být užita, musí být nasazena ihned. “64

Prezident Bush nakonec prosadil kompromis. Invaze proběhla v nebližším možném termínu, do bojové operace však nasadil tolik mužů, kolik si armáda žádala (mezinárodní koalici tvořilo přibližně 550000 vojáků, zhruba tolik jako Američanů ve Vietnamu v době největší eskalace války). Samotná operace probíhala až neočekávaně dobře. Během necelých sedmi týdnů byl Saddám Husajn nucen kapitulovat a vše se jevilo tak, že koalice vedená Spojenými státy svůj cíl splnila. „Tohle je pro Ameriku velký den,“ komentoval dosažené cíle prezident Bush se skupinkou kongresmanů, ,a díky bohu, konečně jsme strašáka Vietnamu navždy pohřbili v písku pouště Arabského poloostrova.“65

Jak se později ukázalo, oslavované vítězství mělo své slabiny. Tím, že Bush považoval svého nepřítele za ekvivalent nacistického diktátora, si uzavřel jakoukoli možnost vyjednávat. Z toho vycházela i jeho vojenská strategie, která počítala s bezpodmínečnou kapitulací. Jestliže však platila analogie s 2. světovou válkou, neměla se operace Pouštní boưre omezit pouze na osvobození Kuvajtu stejně tak, jako se spojenci za 2. světové války nezastavili na hranicích Německa. I když prezident Bush nikdy explicitně netvrdil, že Spojené státy obsadí Irák, způsob, jakým argumentoval, tento scénář podporoval. Jestliže Spojené státy zůstaly po 2. světové válce v Evropě i v Japonsku a byl-li Saddám dalším Hitlerem, jak je možné, že jej ponechaly u moci? V čem měl být Irák jiný, když prezident samotný vytváří paralely mezi událostmi z konce studené války s těmi před 50. lety? ${ }^{66}$

\section{WilliaM J. CLINTON (1993-2001): VÁLKA V KOSOVU}

Vítězství Billa Clintona (1992) představovalo pro Spojené státy zásadní změnu. Zatímco Bush starší patřil ke generaci, která osobně prožila 2. světovou válku, Clinton se narodil až po ní. Jeho chápání světa neutvářel nacismus, Hitler a 2. světová válka, nýbrž bouřivé období 60 . a 70. let a protesty proti vietnamské válce.

Mladý Bill Clinton se povolávacímu rozkazu vyhnul studiem na vysoké škole. V prezidentských volbách roku 1972 se aktivně zapojil do kampaně demokratického kandidáta 
George McGoverna (známého svým radikálním pacifismem). Do vrcholné politiky vstoupil Clinton v pouhých 32 letech (1978) jako guvernér státu Arkansas.

Henry Kissinger si v narážce na Clintonovu minulost postěžoval, že tato generace ,ještě nezrodila vůdce, kteří by ji dokázali získat pro konzistentní a dlouhodobou zahraniční politiku“ 67 Kissingerova poznámka byla narážkou mimo jiné na to, že Clinton se podobně jako Jimmy Carter během své kampaně soustředil na domácí politiku. Mezinárodní politika nepatřila mezi jeho priority a nezkušenost $\mathrm{s}$ formováním zahraničněpolitického konsenzu poznamenala americkou akceschopnost, at' už šlo o krizi v bývalé Jugoslávii nebo Rwandě. Clintonovo mládí a okolnosti, které formovaly jeho politické názory, do značné míry vysvětlují, proč ve svých projevech nepoužíval analogie Mnichova. Na rozdíl od svých předchůdců Clinton pouze výjimečně využíval citací Winstona Churchilla. Neučinil tak dokonce ani v roce 1996, když si svět připomínal 50 let od legendárního projevu o ,železné oponě“ 68

Výjimku v rámci Clintonova kabinetu představovala ministryně zahraničí Madeleine Albrightová. Sama prohlašovala: „Můj pohled na svět určoval Mnichov. Pro většinu z mé generace to byl Vietnam. “69 Podle všeho to byla právě ona, kdo v době kosovské krize prezidentovi poukázal na paralelu s Mnichovem. Prezident Clinton jí využil po zahájení bombardování Srbska (březen 1999) na sjezdu odborů. Své posluchače se snažil přesvědčit následujícím tvrzením: „Je to vše o hodnotách. Kdyby někdo jen poslouchal Winstona Churchilla a povstal proti Adolfu Hitlerovi dříve? Kolik životů by to zachránilo? A kolik Američanů mohlo být zachráněno... Musíme něco dělat... Pokud nepovstaneme proti brutalitě a zabíjení nevinných civilistů, umožňujeme, aby se vrátilo v ještě větších počtech.“70 Odkaz na Mnichov je z výroku sice patrný, nicméně není jasné, na co konkrétně Bill Clinton upozorňoval. Chtěl tím sám sebe přirovnat k Winstonu Churchillovi, aby varoval před Slobodanem Miloševičem jakožto Hitlerem Balkánu? Takové přirovnání pokulhává, protože, pokud by v Bílém domě skutečně seděl „Churchill“, nikdy by nepřipustil, aby Spojené státy s „Hitlerem“ vyjednávaly. Jenže to bylo přesně to, o co americký prezident usiloval. Jestliže by Miloševič byl balkánským „führerem“, pak Clinton většinu svého času v Bílém domě spíše připomínal Chamberlaina, protože celé první volební období pracoval na dojednání Daytonské mírové smlouvy (1995), kterou podepsalo i Srbsko. ${ }^{71}$

Bill Clinton měl pravdu, když naznačoval, že včasný zásah v Jugoslávii již v roce 1991 mohl ušetřit životy mnohých civilistů. Přesto je analogie s Mnichovem, resp. s 2. světovou válkou, zavádějící. „Miloševič má na svých rukou krev. Je hrozbou, zločincem, postkomunistickým bídákem, který cynicky manipuluje nacionalismem ${ }^{72}$ ““ jak poznamenal Timothy G. Ash, ,,ale nikdy nebyl nacionálním socialistou, Srbsko nebylo meziválečným Německem a kosovští Albánci nebyli Židé. Nacistická ideologie i dějinný kontext byly zkrátka natolik unikátní, že bychom je neměli rozřed’ovat politickými konflikty současnosti.“"73

\section{GEORGE W. BUSH (2001-2009): PERSKÝ ZÁLIV II}

Vzhledem k tomu, že analýza Bushovy doktríny byla opakovaně a často připomínána, budeme se v této části soustředit pouze na použití mnichovské analogie v případě druhé války v Iráku. Můžeme konstatovat, že jestliže Bill Clinton používal analogie Mnichova výjimečně, pak vítězství George Bushe mladšího (2000) znamenalo pro Spojené státy plný návrat k mnichovskému paradigmatu.

Když se schylovalo k zásahu proti režimu Saddáma Husajna vedenému Američany, vystoupil v říjnu 2002 prezident George W. Bush v celostátním projevu s tvrzením, že Američané jsou „dnes odhodláni čelit každé hrozbě, od jakéhokoli zdroje, který by Americe mohl způsobit nečekaný teror a utrpení“. ${ }^{74}$ Po několika odstavcích následovala pasáž, kde George Bush cituje projev Johna Kennedyho z října 1962: „Ani Spojené státy americké, ani světové společenství národů nemůže tolerovat úmyslné lhaní a agresivní vyhrožování kterékoli země, at' už velké, nebo malé. Nežijeme ve světě, kde teprve samotné výstřely zbraní představují dostatečnou výzvu národní bezpečnosti, 
aby byly chápány jako největší možná hrozba. “75 Prezident Bush se pokoušel navodit dojem, že Saddám Husajn v roce 2002 představoval stejnou hrozbu jako Fidel Castro, když umožnil Sovětskému svazu zrrízení raketové základny v Karibiku. Prezident Bush upozorňoval, že hrozba útoku nepř́itele je stejně akutní jako před 40 lety a že již není možné dále vyčkávat. Klíčový rozdíl, který ovšem prezident Bush již nepřipomněl, spočíval v tom, že Kennedy se svým vystoupením snažil válce zabránit, kdežto Bush chtěl válku uspíšit a ospravedlnit. Zatímco Kennedy postupoval velmi obezřetně a konzultoval svůj postup se spojenci v NATO, George Bush jednal unilaterálně. Ve snaze získat legitimitu pro svůj postup svolal Kennedy mimořádné zasedání Rady bezpečnosti OSN, kde jeho zástupce Adlei Stevenson předložil fotografie sovětských raketových sil na Kubě. Prezident Bush se rovněž snažil získat přízeň členů OSN, spíše však z formálních důvodů, zejména na naléhání britského premiéra Tonyho Blaira. V 60. letech Kennedy preventivní úder zvažoval, ale dal přednost diplomacii, a tento tah se mu vyplatil.

Další zajímavý výrok, který svědčí o tom, že George Bush ml. zůstal v myšlenkovém zajetí Mnichova, byl pronesen při návštěvě Polska v květnu 2003. Americký prezident zde prohlásil, že pro USA ,byly události z 11. září [2001] tak směrodatné jako útok na Pearl Harbor a zrada jiné září v [roce] 1939. A poučení všech těchto události je stejné: agrese a zlé úmysly nesmějí být ignorovány nebo zmírňovány, musí se jim čelit časně a rozhodně“. ${ }^{76}$ Tento výrok je velmi zjednodušující a zavádějící současně. Zjednodušující proto, že německý útok na Polsko zcela jistě neměl stejné dopady na Spojené státy jako japonský útok na Pearl Harbor. V reakci na napadení Polska dokázal Franklin D. Roosevelt přesvědčit Kongres, aby zrušil Zákony o neutralitě (listopad 1939). Bylo to vůbec poprvé, kdy Bílý dům dokázal porazit jinak převládající izolacionistický konsenzus v Kongresu. To však nic nemění na tom, že na konci roku 1939 byly Spojené státy na válku připraveny asi jako Velká Británie při mnichovské krizi.

Výše uvedený citát je rovněž zjednodušující. Agrese i zlé úmysly by přirozeně neměly zůstat nepotrestány. Otázkou je, jaká odpověd' je nejefektivnější. Jestliže prezident Bush srovnával teroristické útoky s 2. světovou válkou, je zrejejé, že nepochopil rozdíly mezi nimi. Jeho výše uvedená citace byla vyřčena před zahájením invaze do Iráku a měla posloužit jako výzva řešit konflikty vojenskou cestu, přesně jako to měli učinit západní spojenci proti nacistickému Německu. S prezidentem Bushem lze souhlasit, když tvrdí, že s některými aktéry (např. teroristy) nelze vyjednávat. Soudíme však, že vrchní velitel ozbrojených sil USA se nemá rozhodovat a své rozhodnutí ospravedlňovat na základě údajné podobnosti se situací před 70 lety. Nejde ani tak o to, že bychom nemohli najít jisté společné rysy Hitlera s vybranými diktátory současnosti. Problém je, že analogie Mnichova a 2. světové války jsou natolik široké, že mohou být účelově aplikovány prakticky na kohokoli: od al-Káidy po vůdce tzv. darebných států (rogue states). Pokud bychom měli výše uvedená slova brát doslovně, museli bychom se stejně vehementně dožadovat vojenského řešení v případě Severní Koreje nebo Íránu.

\section{ZÁVĚR}

Odborníci zabývající se (nejen) zahraniční politikou se často obracejí na historii, aby vysledovali podobnosti, které mají jistý význam pro dnešek. Hledání a nacházení historických vodítek patř́i mezi pomůcky, které nám umožňují se z vlastních dějin poučit. Objevování historických analogií by se nicméně nemělo stát jediným klíčem, podle něhož se rozhodujeme.

Mnichovská smlouva (1938) jako symbol neúspěšné politiky appeasementu je jedním $\mathrm{z}$ učebnicových př́kladů toho, jak lze takové analogie zneužít. V tomto článku jsme demonstrovali na př́kladu devíti amerických prezidentů, kteří vládli v letech 1945-2009, jak flexibilně lze paradigma Mnichova aplikovat.

Tvrdíme, že opakované dovolávání se mnichovského paradigmatu ve zcela jiném kontextu vychází z chybného pochopení toho, co se v Mnichově odehrálo. Hrozba, kterou tehdy pro svět představovalo nacistické Německo, byla zcela unikátní a neopakovatelná. Také Sovětský svaz měl 
podobné ambice, alespoň za Stalina. Kdykoli byl však vystaven vojenské převaze USA, ustoupil. Jiní diktátoři (Mao Ce-tung, Kim Ir-sen, Fidel Castro) sice měli ambice, ale scházely jim prostředky. Dnes máme dostatečné množství důkazů o tom, že německý vůdce byl rozhodnutý zahájit válku za jakoukoli cenu. Neexistoval žádný prostředek, který by jej odradil, respektive odstrašil nebo usmíril. Jeho konečným cílem bylo zničení mezinárodního řádu. Žádná jiná diktatura 20. století nebyla v tomto ohledu nacismu podobná. Tvrzení, že Kim Ir-sen, Ho Či Min, Slobodan Miloševič nebo Saddám Husajn představují stejnou hrozbu jako Adolf Hitler, jsou zavádějící a nebezpečná zároveň.

Je proto načase si položit otázku, zda analogie Mnichova (ale také Vietnamu) má v zahraničněpolitickém slovníku ještě nějaké místo. Dovolávat se Mnichova může bud' znamenat neschopnost posoudit dvě události, anebo záměrnou snahu apelovat na emoce a tímto způsobem na svou stranu získat širší podporu. Obě varianty považujeme za nepřijatelné.

Odmítnout paradigma Mnichova neznamená zavrhnout vojenské řešení, avšak tam, kde existuje možnost dosáhnout pokroku prostřednictvím jednání, by se mělo stát nevyhnutelným. Vojenské řešení by mělo nastoupit až jako poslední eventualita poté, co ostatní prostředky selžou.

Před bezmála půl stoletím prezident Kennedy ve svém inauguračním projevu (1961) prohlásil, že ,zdvořilost [vůči nepříteli] není značka slabosti a upřímnost je základ pevnosti. Nikdy nevyjednávejme ze strachu, ale nikdy se neobávejme vyjednávat“. ${ }^{77}$ Tato slova vyřčena na vrcholu studené války zůstávají platná i v 21. století. Barack Obama má v tomto smyslu unikátní možnost stát se prvním americkým prezidentem, který se nebude dovolávat Mnichova ani se obávat „dalšího Vietnamu“.

\section{PozNÁMKY}

${ }^{1}$ Bez autora. Reports Prime Minister Neville Chamberlain's Return from Munich, September 30, 1938.

${ }^{2}$ Ibid.

${ }^{3}$ DleSIRACUSA, Joseph M., The Munich Analogy.

${ }^{4}$ RECORD, Jeffrey, Retiring Hitler and „Appeasement" from the National Security Debate, s. 15.

${ }_{6}^{5}$ Ibid., s. 99.

${ }^{6}$ RIPSMAN, Norrin M., LEVY, Jack S., Wishful Thinking or Buying Time? The Logic of British Appeasement in the 1930s, s. 158-179.

${ }^{7}$ RECORD, Jeffrey Retiring Hitler and „Appeasement“ from the National Security Debate, s. 100.

${ }^{8}$ RIPSMAN, Norrin M., LEVY, Jack S., s. 180-181.

${ }^{9}$ WEINBERG, Gerhard L., Úvahy o Mnichovu po šedesáti letech, s. 55-57.

${ }^{10}$ Ibid.

${ }^{11}$ DleEVANS, Harold, BUCKLAND, Gail, BAKER, Kevin, The American Century, s. 423.

${ }^{12}$ DleSIRACUSA, Joseph. M., The Munich Analogy.

${ }^{13}$ Race for the Superbomb - The Korean War.

${ }^{14}$ KISSINGER, Henry, Uméní diplomacie, s. 492.

${ }^{15}$ GADDIS, John Lewis, Studená válka, s. 47-51.

${ }^{16}$ Zpráva NSC - 68 (7. dubna 1950).

${ }^{17}$ EISENHOWER, Dwight D.. Dopis Winstonu Churchillovi., s. 121-122.

${ }^{18}$ EISENHOWER, Dwight D.. Tisková konference, 7. dubna 1954.

${ }^{19}$ Ibid.

${ }^{20}$ ACHESON, Dean (1969), Present at the Creation: My Years at the State Department, nestránkováno.

${ }^{21}$ CONWAY, Paul, A Myth for all seasons, s. 185.

${ }^{22}$ TUCKER, Spencer, Vietnam, s. 77-78.

${ }^{23}$ Dle MBROSE, Stephen E., Rise to Globalism, s. 174.

${ }^{24}$ KISSINGER, Henry, Uméní diplomaice, s. 674.

${ }^{25}$ MOSS, George Donelson, Vietnam: An American Ordeal, s 111-112.

${ }^{26}$ KENNEDY, John F.. Tisková konference, 23. března 1961.

${ }^{27}$ MOSS, George Donelson, Vietnam: An American Ordeal, s. 112. 
${ }^{28}$ KENNEDY, John F.. Televizní projev o budování sovětské raketové základny na Kubě, 22. října 1962.

${ }^{29}$ dle SIRACUSA, Joseph. M., The Munich Analogy.

${ }^{30}$ Mezi stoupence této teorie patří bývalý ministr obrany Robert McNamara, historik Arthur M. Schlesinger jr., William J. Rust, Theodore White, John Newman aj.

${ }_{31}$ NSAM (National Security Action Memorandum), No. 263.

${ }^{32}$ AMBROSE, Stephen E., Rise to Globalism, s. 175.

${ }^{33}$ TUCKER, Spencer, Vietnam, s. 95.

${ }^{34}$ dle RECORD, Jeffrey, Period of Reasoning by Historical Analogy Munich, Vietnam and American use of Force Since 1945, s. 10.

${ }^{35}$ dle SIRACUSA, Joseph. M., The Munich Analogy.

${ }^{36}$ dle MOSS, George Donelson, Vietnam: An American Ordeal, s. 146.

37 JOHNSON, Lyndon B.. Projev na Akron University (Ohio), 21. ř́ina 1964.

${ }^{38}$ The Real Military Flix: Why Vietnam? (1965) A governmental Film Outlining American Policy.

${ }^{39}$ MOSS, George Donelson, Vietnam: An American Ordeal, s. 161.

${ }^{40}$ HLAVÁČEK, Pavel, Ukončení angažovanosti Spojených států ve vietnamské válce, s. 21-23.

${ }^{41}$ Záznam rozhovoru mezi R. Nixonem a $\mathrm{H}$. Kissingerem přehrán v pořadu stanice $\mathrm{ABC}$ „Torn Curtain - The Secret History of the Cold War: Episode 3: The Vietnam War and Richard Nixon's Secret Nuclear Alert“".

${ }^{42}$ SIRACUSA, Joseph. M., The Munich Analogy.

${ }^{43}$ dle AMBROSE, Stephen E., Nixon and Vietnam: Vietnam and Electoral Politics, s. 205.

${ }^{44}$ BERMAN, Larry, No Peace, No Honor, s. 52.

${ }^{45}$ NIXON, Richard M.. Projev o ukončení vietnamské války, 23. ledna 1973.

${ }^{46}$ EISENHOWER, Dwight D. Eisenhower. Projev „Šance pro mir" před American Society of Newspaper Editors, 16. dubna 1953.

${ }^{47}$ GADDIS, John, Studená válka, s. 66.

${ }^{48}$ JANDA, Kenneth, BERRY, Jeffrey, M., GOLDMAN, Jerry, The Challenge of Democracy, s. 694-695.

${ }^{49}$ GADDIS, John Lewis, s. 206-207.

${ }^{50}$ HAYWARD, Steven F. Two Giants.

${ }^{51}$ Ibid.

52 REAGAN, Ronald. Projev na výročním zasedání Národní asociace evangelíků v Orlandu (Florida), 8. března 1983.

${ }^{53}$ Ibid.

${ }^{54}$ REAGAN, Ronald. Projev na výročním zasedání Americké legie, Seattle (Washington), 23. srpna 1983.

${ }_{55}^{5}$ REAGAN, Ronald. Rádiový projev o navýšení obranného rozpočtu, 19. února 1983.

${ }^{56}$ ZAKARIA, Fareed. Who's the Real Appeaser?

${ }^{57}$ Tamtéž.

${ }^{58}$ AMBROSE, Stehen, E., Rise to Globalism, s. 382.

${ }^{59}$ BUSH, George H. W.. Projev o rozmístění americké armády v Saudské Arábii, 8. srpna 1990.

${ }^{60}$ Premiérka Thatcherová se také odkazovala na chybnou politiku z 30 . let, nicméně častěji využívala paralely s válkou o Falklandy (1982).

${ }^{61}$ dle MacDONALD, Scot, Hitler's Shadow: Historical Analogies and the Iraqi Invasion to Kuwait, s. 30.

${ }^{62}$ Ibid., s. 30.

${ }^{63}$ AMBROSE, Stephen, E., Rise to Globalism, s. 388.

${ }^{64}$ MacDONALD, Scot, s. 33.

${ }^{65}$ BUSH, George H. W.. Rozhovor se zákonodárci USA, 1. března 1991.

${ }^{66}$ AMBROSE, Stephen, E., Rise to Globalism, s. 387-388.

${ }^{67}$ KISSINGER, Henry, Potřebuje Amerika zahraniční politiku?, s. 23.

${ }^{68}$ HAYWARD, Steven F. Two Giants.

${ }^{69}$ CNN Profil Madlaine Allbright.

${ }^{70}$ CLINTON, Bill. Projev prezidenta na sjezdu odborů, Washington, 23. března 1999.

${ }^{71}$ ASH, Timothy G.. The New Adolf Hitler?

${ }^{72}$ Ibid.

${ }^{73}$ HAHNOVÁ, Eva. Mnichov je zrádná paralela, s. 24.

${ }^{74}$ BUSH, George W.. Projev národu o Iráku, Cincinnati (Ohio), 7. října 2002.

${ }^{75}$ Ibid.

${ }^{76}$ BUSH, George W.. Projev prezidenta na královském hradě Wawel u Krakova, Polsko, 31. května 2003. 
${ }^{77}$ KENNEDY, John F.. Inaugurační projev, 20. ledna 1961.

\section{LITERATURA}

\section{Monografie}

[1] AMBROSE, Stephen E., Rise to Globalism, American Foreign Policy Since 1938. Pinguin Books, 1993.

[2] BERMAN, Larry, No Peace, No Honor: Nixon, Kissinger, and Betrayal in Vietnam. Touchstone, 2001.

[3] DONALDSON, Gary A., American Foreign Policy, the Twentieth Century in Documents. Longman Publishers, 2003.

[4] EVANS, Harold, BUCKLAND, Gail, BAKER, Kevin, The American Century. Pimplico, 1998.

[5] GADDIS, John Lewis, Studená válka. Slovart, Praha, 2006.

[6] HLAVÁČEK, Pavel. Ukončení angažovanosti Spojených států ve vietnamské válce. Rigorózní práce (nepublikovaná), obhájená na Západočeské univerzitě v Plzni, 2007.

[7] JANDA, Kenneth, BERRY, Jeffrey M., GOLDMAN, Jerry, The Challenge of Democracy. Government in America. Chapter "Foreign and Defense Policy", (pp. 694-679) Houghton Mifflin Society, 1989.

[8] KAGAN, Donald and Frederick W., While America Sleeps. St. Martin's Press, 1998.

[9] KISSINGER, Henry, Umění diplomacie. Praha: Prostor, 1997.

[10] KISSINGER, Henry, Potřebuje Amerika zahraniční politiku?. Praha: BB Art, 2002.

[11] MOSS, George Donelson, Vietnam: An American Ordeal ( $2^{\text {nd }}$ edition). New Jersey: Prentice Hall, 1994.

[12] TUCKER, Spencer C., Vietnam. London: UCL Press, 1999.

\section{Příspěvek ve sborníku}

[13] AMBROSE, Stephen E. (1988). Nixon and Vietnam: Vietnam and Electoral Politics. In MOSS, George Donelson (ed.). A Vietnam Reader. Sources and Essays. New Jersey: Prentice Hall, 1991, s. 201-216.

[14] CONWAY, Paul. A Myth for all seasons: the Domino theory and America's longest war (nedatováno). In MOSS, George Donelson (ed.). A Vietnam Reader. Sources and Essays. New Jersey: Prentice Hall, 1991, s. 181-200.

\section{Článek v internetovém periodiku}

[15] (bez autora) Prime Minister Neville Chamberlain's Return From Munich, September 30, 1938. London Times, October 1.1938 (nečíslováno). In: Donaldson, Gary A., American Foreign Policy - The Twentieth Century, s. 82-85.

[16] APPLEBAUM, Anne. The Hitler Analogy. May 20, 2008. American Enterprise Institute for Public Policy Research. [cit. 2008-12-16] Dostupný z WWW: http://www.aei.org/publications/pubID.28027,filter.all/pub_detail.asp.

[17] ASH, Timothy Garton. The New Adolf Hitler?. The Time, April 5, 1999. [cit. 2008-12-28] Dostupné z WWW: http://www.time.com/time/printout/0,8816,990678,00.html. 
[18] BURUMA, Ian. The Mixed Lessons, and Legacies, of Munich 1938. The Los Angeles Times, September 14, 2008. [cit. 2008-11-15] Dostupné z WWW: http://www.latimes.com/news/opinion/la-oe-buruma14-2008sep14,0,2649053.story (12. 12. 2008).

[19] GOLDBERG, Jeffrey (2008). The Wars of John McCain. The Atlantic.com. [cit. 2008-1213] Dostupný z WWW: http://www.theatlantic.com/doc/200810/mccain.

[20] HAHNOVÁ, Eva, Mnichov je zrádná paralela. Lidové noviny, 27. září 2008, s. 24.

[21] HAIG jr., Alexander M. Gulf Analogy: Munich or Vietnam? The New York Times, 10. December 1990. [cit. 2008-12-12] Dostupný z WW: http://query.nytimes.com/gst/fullpage.html?res=9C0CE3D61E38F933A25751C1A9669582 60.

[22] HAYWARD, Steven F. (2005). Two Giants - Steven Hayward compares Reagan and Churchill. National Review Online. [cit. 2008-12-14] Dostupný z WWW: http://www.nationalreview.com/interrogatory/hayward200510190833.asp.

[23] HAYWARD, Steven F.. The Use and Abuse of Churchill in History. September 11, 2006. American Enterprise Institute for Public Policy Research.

[24] [cit. 2008-12-28] Dostupný Z WW: http://www.aei.org/publications/pubID.24883/pub_detail.asp.

[25] KAPLAN, Robert D. (2007). Foreign Policy: Munich Versus Vietnam. The Atlantic, May 4, 2007. [cit. 2008-8-6] Dostupný http://www.theatlantic.com/doc/print/200705u/vietnam-munich.

[26] MacDONALD, Scot (2002). Hitler's Shadow: Historical Analogies and the Iraqi Invasion of Kuwait. Diplomacy \& Statecraft, Vol. 13, No. 4 (December 2002), pp. 29 - 59.

[27] RECORD, Jeffrey. Period of Reasoning by Historical Analogy Munich, Vietnam and American use of Force Since 1945. Occasional Paper No. 4. Center for Strategy and Technology, Air War College, March 1998. [cit. 2008-10-21]. Dostupný z WWW: http://www.au.af.mil/au/awc/awcgate/cst/csat4.pdf.

[28] RECORD, Jeffrey. Serbia and Vietnam. Preliminary Comparison of the U.S. Decision to Use Force. Occasional Paper No. 8. Center for Strategy and Technology, Air War College, May 1999. [cit. 2008-10-21]. Dostupný z http://www.au.af.mil/au/awc/awcgate/cst/csat8.pdf.

[29] RECORD, Jeffrey. Appeasement Reconsidered: Investigating the Mythology of the 1930s. Strategic Studies Institute, August 2005. [cit. 2008-10-21]. Dostupný z WWW: http://www.strategicstudiesinstitute.army.mil/pdffiles/PUB622.pdf.

[30] RECORD, Jeffrey. Retiring Hitler and "Appeasement" from the National Security Debate. Parameters, Summer 2008, pp. 91-101.

[31] RIPSMAN, Norrin M. - LEVY, Jack S. Wishful Thinking or Buying Time? The Logic of British Appeasement in the 1930s. International Security, Issue 2, Volume 33. pp. 148-181.

[32] SIRACUSA, Joseph M. The Munich Analogy. Encyclopedia of American Foreign Policy (nedatováno, nestránkováno) [cit. 2008-10-21]. Dostupný z WWW: www.americanforeignrelations.com/E-N/The-Munich-Analogy.html.

[33] THOMAS, Evan. The Mythology of Munich. July 23, 2008 Newsweek. [cit. 2008-10-21]. Dostupný z WWW: www.newsweek.com/id/141502/output/print.

[34] WEINBERG, Gerhard L.. Úvahy o Mnichovu po šedesáti letech. Střední Evropa, č. 92/93, roč. 15 (zář́íř́ijen 1999), s. 51-60. 
[35] WHEATCROFT, Geoffrey. 'Munich' Shouldn't Be Such a Dirty Word. Washington Post, Sunday, September 28, 2008, s. B03.

[36] ZAKARIA, Fareed. Who's the Real Appeaser? May 26, 2008 Newsweek. [cit. 2008-10-21]. Dostupný z WWW: http://www.newsweek.com/id/137518.

\section{Internetové stránky}

[37] CNN Profil Madlaine Albright [online], 1997 [cit. 2009-01-08]. Dostupný z WWW: http://edition.cnn.com/ALLPOLITICS/1997/gen/resources/players/albright/.

[38] Race for the Superbomb - The Korean War. [online], 1997 [cit. 2008-12-17]. Dostupný z WWW: http://www.pbs.org/wgbh/amex/bomb/peopleevents/pandeAMEX58.html.

[39] The Real Military Flix: Why Vietnam? (1965) A governmental Film Outlining American Policy. [online] 2008 [cit. 2008-10-11] Dostupný zWWW: http://www.realmilitaryflix.com/public/291.cfm.

[40] Torn Curtain - The Secret History of the Cold War: Episode 3: The Vietnam War and Richard Nixon's Secret Nuclear Alert“. [online] 28 May 2006 [cit. 2006-02-05] Dostupný z WWW: http://www.abc.net.au/rn/history/hindsight/features/torn/episode3.htm.

\section{Zdrojové dokumenty}

[41] ACHESON, Dean. Present at the Creation: My Years at the State Department. New York: W.W. Norton, 1969. (výtažek z knihy) [cit. 2008-12-28]. Dostupný z WWW: http://www.mtholyoke.edu/acad/intrel/acheson3.htm.

[42] ACHESON, Dean. Projev v Národním tiskovém klubu (12. ledna 1950). [cit. 2008-12-16] Dostupný z WWW: http://www.j-bradford-delong.net/TCEH/Acheson_Korea.html.

[43] BUSH, George H. W.. Projev o rozmístění americké armády v Saudské Arábii, 8. srpna 1990. [cit. 2008-12-20] Dostupný http://www.presidency.ucsb.edu/ws/index.php?pid=18750\&st=\&st1=.

[44] BUSH, George H. W.. Rozhovor se zákonodárci USA, 1. března 1991. [cit. 2008-12-11] Dostupný z WWW: http://www.presidency.ucsb.edu/ws/index.php?pid=19351\&st=\&st1=.

[45] BUSH, George W.. Projev národu o Iráku, Cincinnati (Ohio), 7. ř́́jna 2002. [cit. 2008-1220] Dostupný

z WWW: http://www.presidency.ucsb.edu/ws/index.php?pid=73139\&st=\&st1= .

[46] BUSH, George W.. Projev prezidenta na královském hradě Wawel u Krakova, Polsko, 31. května 2003. [cit. 2008-12-19] Dostupný zWW: http://www.presidency.ucsb.edu/ws/index.php?pid=64354\&st=\&st1=(19. 12. 2008).

[47] CLINTON, Bill. Projev prezidenta na sjezdu odborů, Washington, 23. března 1999. [cit. 2008-12-11] Dostupný

z WWW: http://www.presidency.ucsb.edu/ws/index.php?pid=57294\&st=\&st1=.

[48] DONALDSON, Gary A.. American Foreign Policy, the Twentieth Century in Documents. Longman Publishers, 2003.

[49] EISENHOWER, Dwight D.. Projev „Šance pro mír“ před American Society of Newspaper Editors, 16. dubna 1953. [cit. 2008-11-11] Dostupný z WWW: http://www.presidency.ucsb.edu/ws/index.php?pid=9819\&st=\&st1=.

[50] EISENHOWER, Dwight D.. Tisková konference, 7. dubna 1954. [cit. 2008-12-18] Dostupný z WWW: http://www.presidency.ucsb.edu/ws/index.php?pid=10202\&st=\&st1=. 
[51] EISENHOWER, Dwight D.. Dopis Winstonu Churchillovi. In: McMAHON, Robert J. Major Problems in the History of the Vietnam War. Documents and Essays ( $2^{\text {nd }}$ edition). Toronto: D. C. Heath \& Co. Lexington (Massachusetts), 1995, s. 121-122.

[52] JOHNSON, Lyndon B.. Projev na Akron University (Ohio), 21. ř́jna 1964. [cit. 2008-1212] Dostupný z WWW: http://www.presidency.ucsb.edu/ws/index.php?pid=26635\&st=\&st1=.

[53] KENNEDY, John F.. Inaugurační projev, 20. ledna 1961. [cit. 2008-12-25] Dostupný z WWW: http://www.presidency.ucsb.edu/ws/index.php?pid=8032.

[54] KENNEDY, John F.. Tisková konference, 23. března 1961. [cit. 2008-12-18] Dostupný z WWW: http://www.presidency.ucsb.edu/ws/index.php?pid=8547\&st=\&st1 $=\quad\left(\begin{array}{ll}18 . & 12 .\end{array}\right.$ 2008).

[55] KENNEDY, John F.. Televizní projev o budování sovětské raketové základny na Kubě, 22. října $1962 . \quad$ [cit. 2008-12-18] Dostupný http://www.presidency.ucsb.edu/ws/index.php?pid=8986\&st=\&st1=.

[56] McMAHON, Robert J. Major Problems in the History of the Vietnam War. Documents and Essays ( $2^{\text {nd }}$ edition). Toronto: D. C. Heath \& Co. Lexington (Massachusetts), 1995.

[57] MOSS, George Donelson, A Vietnam Reader. Sources and Essays. New Jersey: Prentice Hall, 1991.

[58] NIXON, Richard M.. Projev o ukončení vietnamské války, 23. ledna 1973. [cit. 2008-10-11] Dostupný z WWW: http://www.presidency.ucsb.edu/ws/index.php?pid=3808\&st=\&st1=.

[59] REAGAN, Ronald. Projev na výročním zasedání Národní asociace evangelíků v Orlandu (Florida), 8. března 1983. [cit. 2008-12-15] Dostupný z WWW: http://www.presidency.ucsb.edu/ws/index.php?pid=41023\&st=\&st1=.

[60] REAGAN, Ronald. Projev na výročním zasedání Americké legie, Seattle (Washington), 23. $\begin{array}{lllll}\text { srpna 1983. } & \text { [cit. } & \text { 2008-12-15] }\end{array}$ http://www.presidency.ucsb.edu/ws/index.php?pid=41747\&st=\&st1=.

[61] REAGAN, Ronald. Rádiový projev o navýšení obranného rozpočtu, 19. února 1983. [cit. 2008-12-15] Dostupný z WWW: http://www.presidency.ucsb.edu/ws/index.php?pid=40950.

[62] Zpráva NSC-68 ze 7. dubna 1950. [cit. 2008-12-17] Dostupný zWWW: http://www.fas.org.irp/offdocs/nsc-hst/nsc-68.htm. 